\title{
Appendix 1 \\ The chronology of Piroska Dely's trial, its background and afterlife
}

1939

Piroska Dely works in the Svábhegy Sanatorium (Buda).

1944

March 19

Dely gets an Arrow Cross armband and badge from an Arrow Cross man called Horváth: "I wore them but I was not a member."

October 8

Piroska Dely meets Pista, the finance guard who gives her an Arrow Cross badge.

Sometime during October, on a Saturday

The Nagyatádi (Kertész) Street events: "robbery and plunder" committed by Piroska Dely and Arrow Cross and German soldiers.

October 15

Pál Laub’s (engineer, Csengery Street 47) testimony: Piroska Dely allegedly cursed the Jewish men in front of Csengery Street 45.

(For a reconstruction of the October 15 events, see appendix 3)

1945

February 7

Mrs. Károly Tóth denounces Piroska Dely, Dob Street 74 third floor 32/b who was active under the pseudonyms Etel Simon and/or Eta Pap: "[O]n her command a mother was taken away from her children and deported ... [she wore an] Arrow Cross badge and green shirt."

Note: Based on the People's Tribunal's documentation. 


\section{February 9}

Piroska Dely goes into in pre-trial detention. According to the emergency group's report she denied being an Arrow Cross member. During the house search, several suitcases were confiscated but these were not mentioned later. "Her real name and her role in the Hársfa Street 57 deportation should be clarified."

\section{February 10 and 13}

Piroska Dely's interrogated by Justice Endre Szebenyi.

\section{February 12}

The Hungarian State Police's (HSP - Magyar Állami Rendörség) Political Security Bureau's detective house-searched Dely's Dob Street 74 groundfloor apartment, and reported on the results. Testimonies by Mrs. Dezső Hajós, Mrs. Sándor Waldman, Mrs. Lajos Engel, Mrs. Béla Ruttkay, Mrs. Jenő Rosenthal, interrogation of Simon Zweig.

\section{February 26}

Piroska Dely interrogated in the presence of László Bajor people's prosecutor. Dely goes into pre-trial detention.

\section{February 27}

Dely indicted with illicit traficking (Hungarian Criminal Code 370/1) in the Hársfa Street case.

\section{February 28}

Szamocseta and János Pál janitors "voluntarily” return the stolen goods to Csengery Street 64's tenants. Piroska Dely interrogated by the People’s Tribunal based on Law 1945/81 Act 13.2, and BTK 370/1, that is illicit trafficking, in the presence of Justice Ernő Fogas. She claims to be pregnant, last sexual intercourse December 23, last period December 18. "I regret my partial culpability and I want to fully reimburse for all damage.”

\section{March 5}

Piroska Dely's People's Tribunal trial in the Hársfa Street case. Andor Lichter's testimony changes the course of events.

\section{March 6}

Based on Andor Lichter and Mrs. Béla Krámer's testimonies, the people's prosecutor requests a separate case and the repeated interrogation of Piroska Dely. 


\section{March 12}

Mrs. Ervin Gábor arrived late to the Political Security Bureau and is told that she can give her testimony during the next day's People's Tribunal trial instead.

\section{March 13}

The HSP Political Security Bureau's investigation files were forwarded due to Andor Lichter and Mrs. Béla Krámer's testimonies. Mrs. Ervin Gábor goes to Piroska Dely people's tribunal trial and recognizes the woman in the black coat with the Arrow Cross armband.

Testimonies by Piroska Dely, Mrs. András Veréb, Mrs. József Strucky are given at the Hungarian State Police's Political Security Bureau. Sándor Steiner also present a testimony concerning Csengery Street 45.

\section{March 14}

The Budapest People's Tribunal's 1945/81 public trial presided over by Justice Béla Pálosi. Witnesses: Simon Zweig, Mrs. Sándor Waldman, Mrs. Lajos Engel, Mrs. Jenő Rosenthal, Mrs. Károly Spiegel; Mrs. Béla Ruttkay and Mrs. Dezső Hajós did not come forward. Dely claims that she is not pregnant and speaks no German. Because of the investigation files that belatedly arrived from the HSP Political Security Bureau, the two cases are united and the trial is postponed.

March 16

József Strucky’s testimony at the HSP Political Security Bureau.

March 17

Mrs. Ervin Gábor's testimony at the HSP Political Security Bureau and Pál Laub’s letter to László Bajor people’s prosecutor.

March 24

Mrs. Andor Steiner's testimony at the HSP Political Security Bureau.

March 26

Mrs. Lajos Steiner née Olga Mitzaki’s testimony at the HSP Political Security Bureau.

March 27

Piroska Dely’s indictment. 


\section{March 29}

The additional investigation's protocol is completed.

\section{April 6}

The trial date is set for April 25.

\section{April 25}

Budapest people's prosecutor's trial is presided over by Justice Béla Pálosi. The final judgement establishes that Dely participated in the following atrocities: rounded up Jews, plundered apartments in Nagyatádi (Kertész) Street, led SS soldiers into Csengery Street with a pistol in her hand, and ordered them to fire. The body searching and torturing of Csengery Street 45 Jewish tenants was proven. In Hársfa Street 57 she kicked a child, she took children away from their mothers, she purchased a fur coat and a golden ring from the Arrow Cross. Witnesses: Simon Zweig, Mrs. Gábor Waldman, Mrs. Lajos Engel, Mrs. Jenő Rosenthal, Mrs. Károly Spiegel, Mrs. Ervin Gábor, József Strucky, Mrs. Béla Krámer, Mrs. Lajos Steiner née Olga Mitzaki, Mrs. Andor Steiner, Mrs. Miksa Tenczer, Mrs. András Veréb, Sándor Steiner, Pál Laub, Mrs. Samu Forgács; Mrs. Gábor Waldman did not come forward. Dely says that she was a nurse at the Svábhegy Sanatorium and as such she was under the command of the German Headquarters. Piroska Dely is sentenced to death. She claims to be four months pregnant. She files a clemency appeal. The closed clemency trial supports her appeal because of her two children and pregnant state.

\section{May 8}

László Kerekes MD prison physician diagnoses that Dely is six months pregnant. According to the Budapest People's Tribunal's council records, her appeal was rejected, i.e. the death sentence could be enforced.

\section{May 22}

The High National Council (Nemzeti Fötanács) submits Dely’s clemency appeal to the People's Tribunals' section leader.

\section{May 24}

The National Council of People's Tribunals (NOT) reaches a decision about Piroska Dely's clemency appeal: “[T]he verdict is suspended until [Dely's] accouchement." The case is forwarded to the Ministry of Justice. 


\section{June 1}

The NOT rejects Dely's clemency appeal "because of her extremely severe actions and her brutal demeanor while performing those actions." Only one council member was in favor of clemency because of Dely's pregnancy.

\section{June 2}

The NOT submits the verdict for approval to the Minister of Justice.

\section{June 4}

The High National Council in its response to the verdict - "as a pregnant woman in need of special care [...] which the state may terminate at any time" - proposes the postponement of the execution.

\section{June 7}

The High National Council's three members agree that the decision about the clemency appeal should be suspended until accouchement.

\section{June 15}

The State Secretary of Justice's letter to the Budapest People’s Tribunal: “[U]ntil her accouchement the documents should be filed. Should the accouchement occur report it and send the documents back without delay."

July 24

Justice Béla Pálosi's letter to György Temesvári prison physician inquires after the due date of the accouchement.

\section{September 17}

Another letter to the physician like the first received no response.

\section{October 8}

According to the prison physician the accouchement is to be expected between October 25 and 30.

\section{December 18}

The People's Tribunal's judge's handwritten note to the prison physician: "Has she given birth and is the child alive?" 


\section{6}

\section{January 9}

Atthe request of the Budapest People's Tribunal Piroska Dely states that her last period was in December 1944, she feels no fetal motion, she does not feel pregnant, and she has abdominal pain. Diagnosis: cysta ovarii.

\section{January 10}

The prison physician's report: the tumor could be perceived as an enlarged uterus. The medical report is submitted to the High National Council.

\section{January 16}

Upon receiving the prison physician's diagnosis, the High National Council rejects the clemency appeal.

\section{January 23}

Minister of Justice István Ries requests that "against Piroska Dely justice should ensue without hindrance.”

\section{January 30}

László Rajk, Ferenc Nagy, Zoltán Tildy (members of the High National Council): "[W]e agree that against Piroska Dely justice should ensue without hindrance."

\section{February 1}

Andor Lichter's letter to President of the Republic Zoltán Tildy urging him to reject the clemency appeal.

\section{February 4}

The High National Council's resolution submitted to the National Council of People's Tribunals (NOT): “[W]e agree that against Piroska Dely justice should ensue without hindrance.”

\section{March 22}

The National Council of People's Tribunals submits the High National Council's resolution to the President of the Budapest People's Tribunals' National Council.

\section{March 23}

Execution supervised by Viktor Zucker people's prosecutor.

\section{June 1}

The people's prosecutor requests the bill of costs. 
1947

February 18

The Budapest People's Tribunal failed to deal with the corpus delicti (gold necklace with cross), therefore it should take action.

March 17

The People's Tribunal cannot act because the list of corpora delicti got lost from among the trial documents.

April 30

The Budapest people's prosecutor submits the list of corpora delicti to the Budapest people's tribunal.

\section{8}

May 29

Róbert Apor people's prosecutor requests information about the resolution concerning the corpus delicti.

\section{October 6}

Róbert Apor people's prosecutor repeatedly requests information.

\section{November 4}

The HSP Budapest Police Headquarters investigates whether Sándor Temesvári is Piroska Dely's lawful heir.

December 14

Róbert Apor people's prosecutor repeatedly requests information.

December 29

The Budapest People's Tribunal's announcement: Sándor Temesvári should come forward for a gold necklace with cross.

\section{9}

\section{April 21}

The people's prosecutor's letter to the People's Tribunal: no one has come forward for the object. 


\section{May 9}

The Budapest People's Tribunal auctions off the gold necklace with cross (corpus delicti) because came forward after 30 days.

May 31

Estimated value of the necklace with cross: 2.5 grams, 90 forints.

May 24

Pál Solt people's prosecutor reminds the Budapest People's Tribunal about the case.

July 11

The gold necklace with cross gets auctioned off in the state loan office.

November 11

The Hungarian National Bank sends the gold necklace with cross back because it was sent there by mistake.

November 30

The Budapest criminal court is ordered to issue the cross to the Hungarian National Bank.

December 24

The Metropolitan Financial Authority requests the Budapest People's Tribunal to forward the verdict.

1950

January 5

The Budapest People's Tribunal forwards the requested verdict.

February 20

The necklace was sold for 17 forints and 60 fillérs; the money is transferred to the Hungarian National Bank's Metropolitan Financial Directorate’s account. 
1962

March 22

Tibor Lukács, the President of Chamber at the Budapest Metropolitan Court submits a transcript without a procedural document, therefore the court has no right to start the process of selling the necklace.

\section{2}

March 28

Mrs. Károly Sziklai née Ilona Steiner requests the Metropolitan Funerary Institute issue the court records of Piroska Dely, the murderer of Béla Steiner and István Steiner, who suffered martyrdom. Their names are on the commemorative plaque.

\section{March 28}

The Budapest Metropolitan Court requests the files from the Registrar of the Ministry of Internal Affairs because "the case requires action."

April 13

The file is returned.

May 10

From Tibor Lukács's letter concerning the victims' placement in the Kerepesi Cemetery's Parcel of Martyrs: "From the testimony of the accused person [Piroska Dely] it is apparent that the German SS troops went to the house to search for ammunition and weapons and to collect those who resisted [...] From an upper floor of the house someone shot at the intruding SS, the Germans went upstairs and opened fire. The Germans collected firearms from the house and from elsewhere too. During the trial it was established that someone shot at passing Germans from Csengery 64's windows. [...] In the house several people were shot dead, others got deported. The members of the Steiner family were among those attacked. I am sending this notification per the request of Mrs. Károly Sziklai concerning the dispute around the tombs of Béla Steiner and István Steiner in the Kerepesi Cemetery." 